\title{
SOURCES OF FINANCE FOR RURAL TOURISM IN THE REPUBLIC OF SERBIA
}

\author{
Gordana Radović ${ }^{1}$
}

\section{Summary}

Rural tourism in the Republic of Serbia has not been developed in line with available resources. Insufficient investments as well as undefined strategic development directions are the reason for that. The reason for that are insufficient investments as well as undefined strategic development directions. The aim of this paper is to present sources of financing for rural tourism, i.e. the rural tourism offer in the Republic of Serbia. The paper includes field research method, analyses, syntheses and statistical method. The author concludes that self-financing has been the dominant source of rural tourism financing in the Republic of Serbia so far. Currently, most of the respondents are not realizing their investments due to the insufficient accumulative ability of rural tourism and agriculture, as their related field, but also due to the lack of good external financial resources. In order to develop rural tourism in the Republic of Serbia it is necessary to define financing modalities which include innovative sources of financing for all segments of the rural tourism offer.

Key words: rural tourism, sources of financing, development, the Republic of Serbia

JEL: $R 29, Q 12, Q 14, L 83$

\section{Introduction}

According to the definition most commonly used in literature and widely accepted in the European Union, rural tourism is a form of tourism which encompasses all activities that can take place in rural areas. Rural tourism is one of the most labour intensive industries, thus being a potential contributor to creating new jobs and economic development of rural areas, which is frequently seen as the most significant element in rural development strategies (Mitchell, Hall, 2005). It has been estimated that there are over 50 different forms of rural tourism, which are defined by reasons that bring tourists to rural areas. According to the Organisation for Economic Cooperation and Development (OECD) data, agritourism is the most common form of rural tourism in the European Union. According to (Ciani, 2003), the development of agritourism and joining tourism activities to existing agricultural activities will eventually lead to the improvement of standard of living on farms.

1 Gordana Radović, Ph.D., General manager, "Dnevnik-Poljoprivrednik” AD, Bulevar oslobođenja no. 81, 21000 Novi Sad, Serbia, Phone: +381 641378 643, E-mail: gordana.radovic09@gmail.com. 
According to (Long, Lane, 2000), the rural tourism development in Europe can be divided into two phases: (1) the period until the end of the $20^{\text {th }}$ century; (2) the period from the beginning of $21^{\text {st }}$ century. A significant growth of service providers, number of partnerships, volume of turnover and the development of rural tourism product was recorded in the first phrase of the rural tourism development. "The growth of tourism demand, in the period between 1980 and 2000 in Europe was 52\%, which was the all-time high as compared to other tourism regions" (Boskovic, 2003). According to (Long, Lane, 2000), the second phase of rural tourism development started at the beginning of the $21^{\text {st }}$ century. This phase is more complex and it will review the position of rural tourism in development policies, implementation of those policies, and the role of rural tourism both in the development of the village and in the development process of the entire tourism.

The rural tourism development in the EU region is also the result of continuous financial support. The importance of financial support in the rural tourism development, with the aim of reducing discrepancies between levels of development of rural regions, was emphasized in the Maastricht Treaty, signed in 1992. The Common Agricultural Policy reform, realized at the end of the $20^{\text {th }}$ century, and its action programme, AGENDA 2000, have resulted in the introduction of the rural development policy, with a special emphasis on the rural tourism development. For this purpose, the European Union budget allocated significant financial resources. Since 2007, financing of rural tourism has been realized through European Agricultural Fund for Rural Development (EAFRD).

The rural tourism development has economic, social and political importance. Main features of rural tourism in terms of its economic importance are: (a) the impact on increase in welfare and economic development of local and economic community and the region; (b) the impact on the rise of local population living standards; (c) the impact on social changes in everyday life of local population (Boyne, 2005). Economic effects can be direct and indirect. Direct economic effects are seen through the provision of additional revenues to rural population, valorization of women labour in agricultural households, job creation and economic development of rural areas. If rural tourism products were placed on the foreign market, rural tourism could also influence the balance of payments of the country. Indirect economic effects are manifested through the development of activities related to rural tourism, but they primarily reflect well on the development of agriculture and trade. The development of rural tourism has social and political importance since it is also a means for introducing cultures, history, customs, gastronomy, life styles, which eventually leads to better understanding of different peoples. According to (George et al., 2009), the rural tourism development "cannot be observed solely as an economic growth, but it also has to be observed from the aspect of environmental and social development."

Based on the Organisation for Economic Cooperation and Development (OECD) classification, around $85 \%$ of the Republic of Serbia territory is considered rural. Dominant activity within this area is agriculture, predominantly extensive agriculture. According to the 2012 agricultural census results, there are 628,552 agricultural households on the territory of the Republic of Serbia. Only 78,301 or $12.4 \%$ of households are involved in other profitable 
activities (OPA) in addition to agriculture. The least number of such households can be found in the AP Vojvodina, only 5.7\%, while the most are found in Šumadija and Western Serbia $16.7 \%$ (Bogdanović, Babović, 2014). Analysis of statistical data has shown that the share of rural tourism, as compared to other profitable activities, is negligible, below 1\%. Predominant activities are processing of milk, fruit and vegetable (Agricultural census, 2012.).

Resources required for the development of rural tourism comprise: natural, human, social, physical and financial resources. The Republic of Serbia has high quality natural resources significant for the development of rural tourism. They include: wide variety of landscapes, wealth of flora and fauna, unpolluted air, water and land, an abundance of thermal waters, pleasant climate and alike. As for human resources, it can be pointed out that a part of the population in rural areas is economically inactive and they can be engaged in the rural tourism. Education can be a limiting factor of development, so it is necessary to provide financial resource for the education of population. Social resources which are significant for the development of rural tourism include: rich cultural and historical heritage, preserved distinctive ethnic features, folklore, traditional handicrafts and gastronomy, treasury of folk customs, old crafts and numerous manifestations held in rural areas. The Republic of Serbia does not have appropriate physical resources for the development of rural tourism, due to the fact that public infrastructure, i.e. traffic, telecommunications, power and utilities are all characterized by low quality. Furthermore, signposting is insufficiently developed. In order to develop rural tourism in the Republic of Serbia, it is also necessary to provide required source of finance for each of the above mentioned resources. Consequently, these resources will be valorised on the market, that is, they will be used for the development of rural tourism. Having analysed given data, it can be concluded that financial resources are one of the most significant limitations of the rural tourism development in the Republic of Serbia (Radović, 2015).

The purpose of this paper is to show the sources of financing for rural tourism and tourist offer in the Republic of Serbia so far. Also, it is necessary to provide sources for financing the rural tourism demand for the development of rural tourism in the Republic of Serbia, but that issue requires separate research and analysis.

\section{Literature Overview}

The issue of rural tourism financing has not been sufficiently studied in the available literature. Below is the list of relevant sources which can be used as a starting point for the research.

According to (Sznajder et al., 2009) the development of rural tourism is related to: natural, demographic, infrastructural and financial resources as well as the government support in the field of rural and regional development. The above mentioned point of view is particularly important for this paper since it points out the importance of financial resources and government support for the development of rural tourism. According to (Svržnjak et al., 2014) financing is usually the most difficult part of rural tourism development because, as some studies show, finding the means of financing is the most time (resource) consuming for developing (implementation) of rural tourism projects. 
According to (Berst, Adams, 2008) rural tourism is a segment of multifunctional rural development and precursors for its development are: (a) demographic factors; (b) natural resources; (c) available funds; (d) state policy in the field of regional and agricultural development; (e) infrastructural development (traffic and social).

Rural tourism financing is directly linked with the financing of agriculture. According to (Todorović, Štetić, 2009) there are significant connections between agriculture and tourism. These economic activities are complementary and multiply connected. Agriculture is the producer, while tourism is the consumer of agricultural products. Furthermore, according to the authors cited above, rural tourism is an important factor of the development tendencies of rural areas, additional activity of rural population, market of agricultural products, a component of agricultural development and a "softener" of depopulation. Hence, due to the unfavourable economic position of agriculture and insufficient accumulation of this economic branch, the rural tourism financing is aggravated.

According to the World Tourism Organisation, major economic significance of the rural tourism is its ability to eliminate poverty ("tourism helps poverty elimination "). Rural tourism is mostly developed in regions with limited financial, but exceptional natural resources which could serve as a platform for agricultural development (Jing, 2006).

According to (Roberts, Hall, 2003) rural tourism can be relatively "sensitive" element of rural development. These authors have classified financial resources as limiting factors. More specifically, they say that investments, setting up new companies and employing people can be restricted by low turnover. Furthermore, the high season is frequently short, which means a short period for income generation, that is, "supply of capital".

Problems related to the development of rural tourism in the Republic of Serbia are: (a) the lack of Register and defined rural tourism standards; (b) insufficient affiliation of service providers within rural tourism, as well as their education; (c) insufficient supply of tourist facilities; (d) undeveloped infrastructure and signposting; (e) incompatibility of rural tourism subjects prescribed by law with actual situation; (f) undeveloped tourist mediation, that is insufficient engagement of tourist agencies in the promotion and sales of rural tourism product (Radović, 2013). In order to overcome above mentioned problems, it is necessary to provide financial resources, that is, modalities of financing.

More precisely, it is necessary to define modalities of financing of rural tourism development in the narrow, but also in a wider sense. Financing the development of rural tourism offer in the narrow sense comprises financing of accommodation development, ancillary equipment and catering facilities. Also, in order to develop rural tourism in the Republic of Serbia it is necessary to define modalities of financing the development of rural tourism offer in a wider sense. Proposed aspects include financing the development of: rural infrastructure, personnel, facilities, promotions and distribution channels (Radović, 2015).

Examples of some European countries with developed rural tourism prove that in the initial stage of the development, the financial support of the state is necessary. According to (Bonham, Mak) until 1993, governments of all states in the United States of America were 
financing the promotion of tourism and travelling within the USA.

According to (Bakić, Hrabovski-Tomić, 2010) economic support of the government for the development of tourism is seen through monetary and fiscal policy. For the $\mathrm{a} / \mathrm{m}$ authors, economic support of the government means direct investments of the state from the budget and other funds, attracting foreign donors, granting development loans as well as subsidized interests. All these forms of economic support are also crucially important for the development of rural tourism.

Potential sources of financing of rural tourism in the Republic of Serbia could also come from loans given by specialized agricultural banks. According to the potential concept, the specialized agricultural bank should consolidate all existing ways of providing agricultural loans from the state budget. Initial capital of this bank could also be provided from the funds of current specialized state financial institutions which provide loans for agriculture, but also from funds generated from the lease of state agricultural land. Loans issued by specialized agricultural banks would provide efficient financing, strategically directed agricultural development, as well as rural development on the entire territory of the Republic of Serbia (Radović, 2014).

Sources cited from the available literature point out the importance of financial resources for the development of rural tourism and indicate potential sources of financing of this activity.

\section{Methodology and Data Sources}

The subject of the research is to define the source of financing of rural tourism in the Republic of Serbia so far from the aspect of rural tourist offer observed in the narrow sense. The paper has used field research method, analyses, syntheses as well as statistical method. The field research method has been implemented in order to gather data on sources of financing of rural tourism offer. The statistical method has been used for processing of data obtained through surveys, while analysis and synthesis method are applied for the purpose of drawing conclusions based on conducted research.

Random sampling is used for obtaining a sample. The National Association "Rural Tourism of Serbia" database is used for creating the sample. This database provides the most complete overview of the rural tourism offer since the Republic of Serbia does not have the Register of Tourism and hence the rural tourism register. Data sources in carried out surveys are subjects of rural tourism: rural households, homecraft, ethno houses, ethno villages, salashes (traditional farms in Vojvodina), hotels located in rural areas, as well as other service providers in the field of rural tourism in the Republic of Serbia.

According to the National Association "Rural Tourism of Serbia" database, on 31 December 2012, there were 950 service providers in rural tourism on the territory of the Republic of Serbia. Having in mind that 104 subjects have been included in the research, which is $10.95 \%$ of the total number of service providers in rural tourism in the Republic of Serbia in the observed period. The research was conducted in the period between June 2012 and October 2013. 
The survey covered rural tourism subjects within districts and municipalities of the Republic of Serbia, which had the largest rural tourism offer in the observed period. The districts in question are the following: South of Bačka, South of Banat, Kolubara, Mačva, Moravica, Pirot, North of Bačka, Srem, Šumadija, West of Bačka and Zlatibor district. Respondents from the $\mathrm{a} / \mathrm{m}$ districts involved in the survey come from the following municipalities: Arilje, Aranđelovac, Bajina Bašta, Čajetina, Dimitrovgrad, Gornji Milanovac, Irig, Ivanjica, Kosjerić, Kragujevac, Kovin, Kula, Kovačica, Knić, Loznica, Ljig, Ljubovija, Mali Iđoš, Mionica, Novi Sad, Nova Varoš, Osečina, Prokuplje, Prijepolje, Pirot, Požega, Sombor, Subotica, Srbobran, Užice and Valjevo.

\section{Research Results and Discussion}

The results of the survey regarding sources of financing for rural tourism offer on the territory of the Republic of Serbia so far are as follows: (Radović, 2015)

[1] 71 respondents $(68.1 \%)$ used self-financing as a source of financing;

[2] 6 respondents $(5.7 \%)$ used other sources of financing, in addition to self-financing;

[3] 3 respondents (2.8\%) used self-financing and subsidies of the Ministry of Agriculture of the Republic of Serbia;

[4] 3 respondents $(2.8 \%)$ used self-financing and bank loans as sources of financing;

[5] 3 respondents $(2.8 \%)$ used self-financing and subsidies of the AP Vojvodina Secretariat as sources of financing;

[6] 2 respondents (1.8\%) used self-financing, subsidies of the Ministry of Agriculture of the Republic of Serbia and other sources of financing;

[7] 1 respondent (1\%) used self-financing and loans provided by the Development Fund of the Republic of Serbia as a source of financing

[8] 1 respondent (1\%) stated that they only used subsidies of the Ministry of Agriculture of the Republic of Serbia as a source of financing;

[9] 1 respondent $(1 \%)$ stated that they used local government subsidies as a source of financing;

[10] 1 respondent (1\%) stated that they used bank loans as a source of financing;

[11] 1 respondent (1\%) stated that they used self-financing and local government subsidies as sources of financing;

[12] 1 respondent (1\%) stated that they used self-financing, loans provided by the Development Fund of the Republic of Serbia and bank loans as sources of financing;

[13] 1 respondent (1\%) used self-financing, subsidies of the AP Vojvodina Secretariat and bank loans as sources of financing;

[14] 1 respondent (1\%) used self-financing, subsidies of the Ministry of Agriculture of the 
Republic of Serbia and bank loans and other sources of financing;

[15] 1 respondent (1\%) used self-financing, subsidies of the AP Vojvodina Secretariat, foreign donations - cross border cooperation projects and other sources of financing;

[16] 1 respondent (1\%) stated that they used self-financing, subsidies of the AP Vojvodina Secretariat, local government subsidies, foreign donations - cross border cooperation projects as sources of financing;

[17] 1 respondent (1\%) stated that they used self-financing, subsidies of the Ministry of Agriculture of the Republic of Serbia, local government subsidies and bank loans;

[18] 1 respondent (1\%) stated that they used self-financing, bank loans, subsidies of the AP Vojvodina Secretariat, local government subsidies and other sources of financing;

[19] 1 respondent (1\%) stated that they used self-financing, subsidies of the Ministry of Agriculture of the Republic of Serbia, bank loans and subsidies of the AP Vojvodina Secretariat as sources of financing;

[20] 1 respondent (1\%) stated that they used self-financing, subsidies of the Ministry of Agriculture of the Republic of Serbia, loans provided by the Development Fund of the Republic of Serbia, bank loans, subsidies of the AP Vojvodina Secretariat and local government subsidies as sources of financing;

[21] 1 respondent (1\%) stated that they used self-financing, subsidies of the Ministry of Agriculture of the Republic of Serbia, loans provided by the Development Fund of the Republic of Serbia, bank loans and other sources of financing;

[22] 1 respondent (1\%) stated that they used subsidies and loans provided by the Ministry of Economy of the Republic of Serbia as sources of financing.

By analysing and summarizing results of the statistical data processing it can be concluded that self-financing had dominant role in the structure of sources of financing of rural tourism in the Republic of Serbia so far. This source of financing was used by $68.1 \%$ of respondents, while combined with other sources it was used by $27.9 \%$, that is $96 \%$ of rural tourism providers used self-financing as the only or additional source of financing.

In addition to self-financing, sources of financing of rural tourism in the Republic of Serbia included: (a) subsidies of the Ministry of Agriculture, Forestry and Water Management; (b) subsidies of the Ministry of Economy; (c) loans provided by the Ministry of Economy issued through the Development Fund of the Republic of Serbia; (d) subsidies of the Provincial Secretariat for Agriculture, Forestry and Water Management; (e) subsidies of the Provincial Secretariat for Economy; (f) local government subsidies; (g) business bank loans; (h) foreign donations from the $\mathrm{CBC}$ projects; (i) donations provided by the Millennium Development Goals Achievement Fund of the Government of the Kingdom of Spain; (j) donations provided by the Global Environmental Fund (GEF); (k) donations provided by Sweden in cooperation with the International Management Group $(I M G) ; 1)$ donation provided by the US Agency for International Development (USAID). 
In the previous period, the initiation of development of rural tourism in the Republic of Serbia has largely been stimulated by foreign sources of co-financing. Their value cannot be appreciated only in terms of quantity, but also through quantitative guidance of the rural tourism development (Radović, Pejanović, 2015).

Graph 1. Experience with bank loans

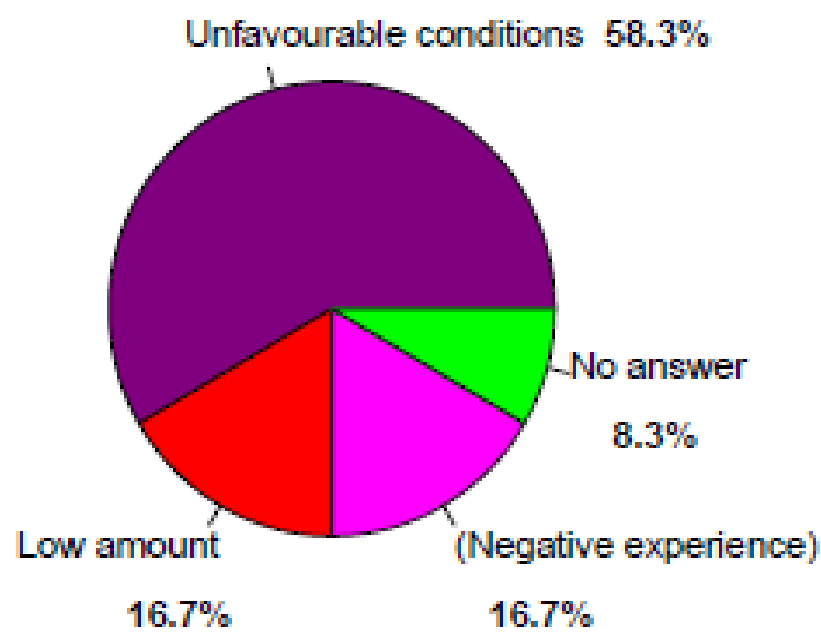

Source: Radović, 2015.

The following section deals with statistical analysis findings of the survey related to the satisfaction of respondents with individual sources of financing. According to these results, as much as $58.3 \%$ of respondents stated that bank loans are characterized by "unfavourable conditions". $16.7 \%$ of respondents had bad experience with this source of financing, while $16.7 \%$ of respondents stated "low amounts" as the main disadvantage of this kind of financing. $8.3 \%$ of respondents did not answer the question, so it can be assumed that they did not use bank loans as the source of financing for the rural tourism. (Graph 1.)

According to statistical analysis results of the survey, $63.6 \%$ of rural tourism subjects had positive experience with subsidies of the Ministry of Agriculture, Forestry and Water Management of the Republic of Serbia. Out of the total number of respondents, $18.2 \%$ had negative experience. The structure of respondents with negative experience is the following: 9.1\% respondents stated "high participation rate" as a negative feature, while $9.1 \%$ pointed out that "lengthy procedures" are a downside of this kind of financing. This question was not answered by $18.2 \%$ of subjects, so it can be assumed that they did not use this source of financing. (Graph 2.) 
Graph 2. Experience with subsidies of the Ministry of Agriculture of RS

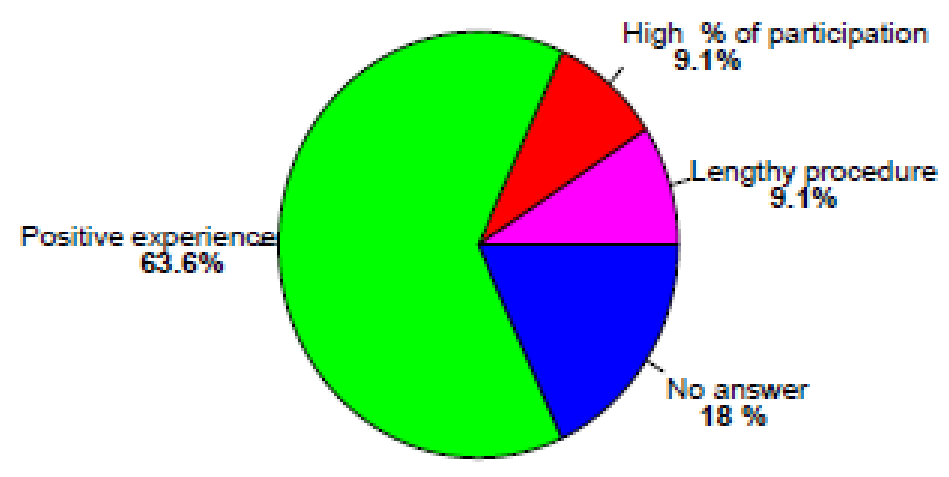

Source: Radović, 2015.

Based on survey results regarding sources of financing of rural tourism offer on the territory of the Republic of Serbia, in the current period, it can be said that the highest percentage of respondents $(56.7 \%)$ have no current investments. The second highest number $(37.5 \%)$ is taken by subjects who are currently realizing their investments and finance them from their own sources (self-financing) 1.8\% of subjects finance their current investments using selffinancing and bank loans, while the remaining subjects combine self-financing with some form of government support (Table 1.).

Table 1. Sources of financing of current investments

\begin{tabular}{|c|c|c|}
\hline Sources of financing & $\begin{array}{c}\text { Frequency } \\
\text { (number of respondents) }\end{array}$ & Percentage (\%) \\
\hline - self-financing & 39 & 37.5 \\
\hline $\begin{array}{c}\text { - self-financing and subsidies of the } \\
\text { Provincial Secretariat }\end{array}$ & 1 & 1.0 \\
\hline $\begin{array}{c}\text { - self-financing and local government } \\
\text { subsidies }\end{array}$ & 1 & 1.0 \\
\hline - self-financing and bank loans & 1 & 1.8 \\
\hline $\begin{array}{c}\text { - self-financing and other methods } \\
\text { (subsidies and loans of the Ministry } \\
\text { of Economy of the Republic of Serbia }\end{array}$ & 1 & 1.0 \\
\hline $\begin{array}{c}\text { - local government subsidies and } \\
\text { subsidies of the Ministry of } \\
\text { Agriculture of the Republic of Serbia }\end{array}$ & 59 & 1.0 \\
\hline - no current investments & 104 & 56.7 \\
\hline & & 100.0 \\
\hline
\end{tabular}

Source: Radović, 2015.

It can be concluded that majority of rural tourism subjects in the Republic of Serbia in the current period does not realize their investments due to the lack of financial resources, that is, adequate modalities of financing. The absence of financial resources is the consequence EP 2016 (63) 3 (1053-1065) 
of insufficient accumulative ability of rural tourism and agriculture as well as the lack of high quality external sources of financing. The cause of insufficient accumulative ability of rural tourism is inefficient exploitation of accommodation facilities. According to statistical analysis findings, the largest share of rural tourism subjects $(39.4 \%)$ had up to 100 nights spent at their accommodation. This result indicates low cost effectiveness and insufficient accumulation and potential for self-financing of rural tourism in the Republic of Serbia. The lack of financial resources for subjects of rural tourism is also the result of low accumulation of agriculture, as its complementary activity, having in mind that $72.1 \%$ respondents stated that they are equally involved in agriculture and rural tourism (Radović, 2015).

It is worth noting that majority $(51.9 \%)$ of respondents, without current investments, stated that they are planning to invest in the development of rural tourism within the next five years. According to statistical analysis findings, respondents stated that sources of financing for their future investments will be: (a) their own funds $-60.7 \%$ respondents; (b) government subsidies $-22.6 \%$ respondents; (c) business banks loans $-7.1 \%$ respondents; (d) cross-border cooperation funds $-2.4 \%$ respondents, (e) loans obtained from foreign investment funds $-1.2 \%$ respondents; while $6 \%$ of respondents did not give a specific answer (Radović, 2015).

\section{Conclusions and Recommendations}

The development of rural tourism in the Republic of Serbia is a complex process considering the fact that rural regions are classified as the most heterogeneous in Europe in terms of natural, economic, demographic and social conditions. Hence, it is essential to treat development of rural tourism as multi-sectoral in the future. It should lay its foundation on adequate legal and strategic framework, accurate action plans, which will define both sources of financing and monitoring of results achieved.

Based on the survey results, it can be concluded that self-financing has been a predominant source of financing of rural tourism in the Republic of Serbia so far, given that $96 \%$ of respondents used self-financing as the only or additional source of financing. Rural tourism service providers chose to self-finance their activity due to the insufficient government support and unfavourable bank loans.

Currently, most respondents do not realize their investments owing to the lack of financial resources caused by insufficient accumulative ability of rural tourism and agriculture and absence of good external sources of financing. The cause of insufficient accumulative ability of rural tourism is inefficient exploitation of accommodation facilities. The lack of sources of financing for service providers in rural tourism is also a result of low accumulation of agriculture, as its complementary activity, since $72.1 \%$ respondents stated that they are equally involved in agriculture and rural tourism. Respondents who realize their investments in the current period primarily finance them from their own funds, because of the lack of high quality external sources of financing. Most of the respondents, although without current investments, stated that they plan to invest in the development of rural tourism in the next five years. In order not to form their views solely on optimism, it is necessary to define modalities 
of financing of all segments of rural tourism offer in the period to come.

Having in mind that the development of rural tourism in the Republic of Serbia, as compared to countries in the region with a similar development period, is still in its initial stage, it is necessary to make government financial support a dominant source of financing. Due to the limited capabilities of state, provincial and local government budgets, it is necessary to examine the possibility for implementing the concept of a specialized agricultural bank. As a development financial institution, this bank would grant loans for priority development projects in the field of rural tourism under more favourable conditions. Thus, it is necessary to adopt the Strategy for Rural Tourism Development, annual programs and action plans regarding the rural tourism development as well as regular monitoring of implementation of plan documents.

Also, it is necessary to develop innovative sources of financing of all segments of rural tourism offer. More precisely, it is necessary to provide financing of rural tourism based on market principles. The market, here, refers to the perfect competition market in terms of its involvement in domestic banking market, in addition to business banks and other financial institutions, such as micro-credit organizations and savings and credit cooperatives.

\section{Literature}

1. Bakić, O., Hrabovski-Tomić, E. (2010): Turizam - pojmovi, efekti, funkcionisanje, Univerzitet Educons, Fakultet poslovne ekonomije, Sremska Kamenica, Srbija.

2. Bogdanov, N., Babović, M. (2014): Radna snaga i aktivnosti poljoprivrednih gazdinstava, Republički zavod za statistiku, Beograd, Srbija.

3. Boyne, S. (2005): New Directions in Rural Tourism Impact Research, in New Directions in Rural Tourism, Hall D., Roberts L. and Mitchell M. (eds), Ashgate Publishing Limited, pp.19-37, Aldershot, England.

4. Berst, Adams, B. (2008): The New Agritourism: Hosting Community \& Tourists on your Farm, pp.46-47, New World Publishing, California.

5. Bonham, C., Mak, J.: Private versus Public Financing of State Destination Promotion. (available at: http://jtr.sagepub.com/content/35/2/3.short)

6. Bošković, N. (2003): Dinamičke promene razvoja svetskog ruralnog turizma, Zbornik radova, Drugi Forum: Ruralni turizam i održivi razvoj Balkana, 07.-09. May 2003., pp. 63-68, Kragujevac, Srbija.

7. Ciani, A. (2003): The Multifunctionality into Managerial Approach as the Challange towards the Renaissance of Rural Areas in the 21th Century, the Role of Rural Tourism and Agritourism, Zbornik radova, Drugi Forum: Ruralni turizam i održivi razvoj Balkana, 07-09. May 2003., pp. 5-24, Kragujevac, Srbija.

8. George, W., Mair, H., Reid, D. (2009): Rural tourism Development Localism and Cultural Change, Channel view Publicatios, Toronto, Canada.

9. Jing, X. (2006): Rural Tourism and Sustainable Community Development, International Forum on Rural Tourism, China, 04-06. September 2006., Final 
Report World Tourism Organization.

10. Long, P., Lane, B. (2000): Trends in Outdoor Recreation. Leisure and Tourism, in Rural Tourism Development, W.C. Garner and D.W. Lime (eds), pp. 299-308, CAB Onternational, Wallingford, USA.

11. Mitchell, M., Hall, D. (2005): Rural Tourism as Sustainable Business: Key Themes and Issues, in Rural Tourism and Sustainable Business, Hall D., Kirkpatrick I. and Mitchell M. (eds), Channel View Publications, pp. 3-14,Clevedon, Buffalo, Toronto, Canada.

12. Radović, G. (2013): Problemi u razvoju ruralnog turizma u Republici Srbiji, Agroekonomika, No. 59-60, Univerzitet u Novom Sadu, Poljoprivredni fakultet, Departman za ekonomiku poljoprivrede i sociologiju sela, pp. 114-123, Novi Sad, Srbija.

13. Radović, G. (2014): Finansiranje poljoprivrede u Republici Srbiji, Monografija, Zadužbina Andrejević, Beograd, Srbija.

14. Radović, G. (2015): Modaliteti finansiranja ruralnog turizma u Republici Srbiji, Doktorska disertacija, Poljoprivredni fakultet, Novi Sad, Srbija.

15. Radović, G., Pejanović, R. (2015): Foreign co-financing sources as a factor of development of rural tourism in the Republic of Serbia, In: Thematic Proceedings, International Scientific Conference: Sustainable Agriculture and Rural Development in Terms of the Republic of Serbia Strategic Goals Implementation within Danube Region - regional specificities; pp. 569-585; Publisher: Institute of Agricultural Economics, Belgrade, Serbia.

16. Radović, G. (2015): Značaj finansiranja za razvoj ruralnog turizma u Republici Srbiji, Agroekonomika, No. 68; Univerzitet u Novom Sadu Poljoprivredni fakultet Departman za ekonomiku poljoprivrede i sociologiju sela, pp. 15-25, Novi Sad, Srbija.

17. Republički zavod za statistiku (2013): Popis poljoprivrede 2012 - Poljoprivreda u Republici Srbiji, Sveska 1, Beograd, Srbija.

18. Roberts, L., Hall, D. (2003): Rural tourism and recreation: principles to Practise, CABI Publishing, Oxon, UK.

19. Svržnjak, K., Kantar, S., Jerčinović, S., Kamenjak, D. (2014): Ruralni turizam uvod u destinacijski menadžment, Visoko gospodarsko učilište, Križevci, Hrvatska.

20. Sznajder, M., Przezborska, L., Scrimgeour, F. (2009): Agritourism, CAB International- CABI, Oxfordshire, UK, Cambridge, USA.

21. Todorović, M., Štetić, S. (2009): Ruralni turizam, Univerzitetu Beogradu, Geografski fakultet, Beograd, Srbija. 


\title{
IZVORI FINANSIRANJA RURALNOG TURIZMA \\ U REPUBLICI SRBIJI
}

\section{Gordana Radovic ${ }^{2}$}

\begin{abstract}
Sažetak
Republika Srbija nema razvijenostruralnog turizma adekvatnu resursima sa kojima raspolaže. Razlog tome su nedovoljna finansijska ulaganja, kao i nedefinisanje jasnog strateškog pravca razvoja. Cilj rada je da prikaže izvore finansiranja ruralnog turizma, odnosno ruralne turističke ponude u Republici Srbiji. U radu su korišćeni metod terenskog istraživanja, analize, sinteze, kao i statistički metod. Autorka zaključuje da je samofinansiranje dominantan izvor finansiranja ruralnog turizma u Republici Srbiji u dosadašnjem periodu. U aktuelnom trenutku većina anketiranih subjekata ne realizuje investicije usled nedovoljne akumulativne sposobnosti ruralnog turizma i poljoprivrede, kao delatnosti s kojom je povezan, ali i zbog nedostatka kvalitetnih eksternih izvora finansiranja. U cilju razvoja ruralnog turizma $u$ Republici Srbiji potrebno je definisanje modaliteta finansiranja, koji uključuju i inovativne izvore finansiranja svih segmenata ruralne turističke ponude.
\end{abstract}

Ključne reči: ruralni turizam, izvori finansiranja, razvoj, Republika Srbija

2 Dr Gordana Radović, Direktor, "Dnevnik-Poljoprivrednik" AD, Bulevar oslobođenja 81, 21000 Novi Sad, Srbija, Telefon: +381 641378 643, E-mail: gordana.radovic09@gmail.com. 